\title{
Adsorption of Antimony(III) onto Fe(III)-Treated Humus Sludge Adsorbent: Behavior and Mechanism Insights
}

\author{
Ren-Jian Deng ${ }^{1-3 *}$, Rang Shao', Bo-Zhi Ren', Baolin Hou', \\ Zhi-E Tang ${ }^{1}$, Andrew Hursthouse ${ }^{1}$ \\ ${ }^{1}$ School of Civil Engineering, Hunan University of Science and Technology, Xiangtan, China \\ ${ }^{2}$ School of Resource Environment and Safety Engineering, Hunan University of Science and Technology, \\ Xiangtan, China \\ ${ }^{3}$ Hunan Jing Yi Environmental Protection High Tech Development Co. Ltd., Xiangtan, China
}

Received: 15 October 2017

Accepted: 15 February 2018

\begin{abstract}
In this study, adsorption behaviors and mechanisms of $\mathrm{Sb}$ (III) ions onto $\mathrm{Fe}$ (III)-treated humus sludge adsorbent (FTHSA) from aqueous solutions was investigated using batch adsorption techniques, Fourier transform infrared (FT-IR) spectra and scanning electron microscopy were coupled to an energy-dispersive spectrometer (EDS). FTHSA was prepared via immersion with $1 \mathrm{~mol} / \mathrm{L}$ $\mathrm{FeCl}_{3}$. The effects of dosage, contact time, $\mathrm{Sb}$ (III) initial concentration, and $\mathrm{pH}$ on the adsorption of $\mathrm{Sb}$ (III) onto FTHSA were investigated. $\mathrm{Sb}$ (III) adsorption was favored at $\mathrm{pH}$ with 2.0 and decreased dramatically with increasing $\mathrm{pH}$. The description of equilibrium data of $\mathrm{Sb}(\mathrm{III})$ adsorption by Langmuir, Freundlich, and Dubbin-Radushkevich isotherm models showed that Langmuir model provided the best fit for $\mathrm{Sb}(\mathrm{III})$ adsorption with maximum adsorption amount of $9.433 \mathrm{mg} / \mathrm{g}$. Pseudo first-order, pseudo second-order, Elovich, and intraparticle diffusion model were applied to describe the adsorption process of $\mathrm{Sb}$ (III) ions onto FTHSA. The results showed that the pseudo second-order model described well how $\mathrm{Sb}(\mathrm{III})$ adsorption and chemical adsorption played a dominant role in the adsorption process. The FT-IR spectra also indicated that the chemical interactions as ion exchange among the metal ions and $\mathrm{N}-\mathrm{H}, \mathrm{O}-\mathrm{H}, \mathrm{C}=\mathrm{O}, \mathrm{COO}$, and $\mathrm{C}-\mathrm{O}$ were mainly involved in the adsorption process. Therefore, FTHSA has a suitable potential removal for $\mathrm{Sb}(\mathrm{III})$ ions in the practical process.
\end{abstract}

Keywords: antimony (III), humus sludge adsorbent, Fe(III)-treated, adsorption isotherm, kinetic model

*e-mail: 800912deng @sina.com 


\section{Introduction}

Antimony (Sb) is mainly found in only oxidation states (III, V) at $\mathrm{pH}$ of 2 10 in natural water environment [1]. Human exposure to $\mathrm{Sb}$ is primarily accumulated through drinking water and the food chain, causing damage to the liver, lungs, and cardiovascular system [2]. $\mathrm{Sb}$ and its compounds have far-reaching impacts because of its strong mobility and complexation reactions in the environment [3], and are considered global pollutants and priority control pollutants by many countries or regions [4]. However, $\mathrm{Sb}$ is widely used in various industries such as alloys, glasses, plastics, and batteries, making waste incineration an important source of $\mathrm{Sb}$ to the water environment [5]. China is the largest $\mathrm{Sb}$ producer in the world with approximately $90 \%$ of the world's production [6]. Due to the complex characteristics of wastewater containing antimony, the lack of latest technology and chaotic management, etc., many surface and ground waters are seriously polluted by the Sb-containing wastewater with large discharge standard in China [78]. Therefore, $\mathrm{Sb}$ poisoning and pollution events should concern scientists in China.

Some treatment methods for $\mathrm{Sb}$ have been developed in the past few decades, such as coagulation precipitation, the biological method, and adsorption and electrochemical methods, etc. [4]. Among them, biosorbents in the genre of Lichens [9], cyanobacteria [10], seaweed [11], sludge [12-13] and other waste materials have performed well in the sequestration of $\mathrm{Sb}$ ions from aqueous solutions. Owing to the advantages of large adsorption capacity, low cost, and being widely sourced, the sludge adsorbents that contain carboxyl, amino, hydroxyl, and phosphoric acid groups are applied to removal harmful heavy metals ions from solution by some researchers [14-15]. Meanwhile, granulation and modification technologies were be developed for overcoming the shortcomings of the poor separation of muddy and water and the low adsorption capacity [4, 16-17]. Moreover, Fe(III) modification technology is considered to be one of the best modifications and strengthening technologies for $\mathrm{Sb}$ removal [12-13, 18]. However, humus sludge and $\mathrm{Fe}(\mathrm{III})$-modification technology for removing antimony is rarely reported. So, influencing factors and adsorption mechanisms are not clear and need to be further studied.

The aims of this paper are to: (1) prepare $\mathrm{Fe}(\mathrm{III})$ treated humus sludge adsorbent (FTHSA), (2) characterize the structural and surface characteristics of FTHSA by Fourier transmission infrared spectroscopy (FT-IR) and scanning electron microscope (SEM), and (3) survey the influence factors, adsorption isotherm, and kinetics consequence of $\mathrm{Sb}$ (III) iron onto FTHSA by using batch equilibration method. The results of this paper may provide theoretical and technical support for the treatment of antimony-containing wastewater.

\section{Material and Methods}

\author{
Humus Sludge and FTHSA
}

Fresh sludge was collected from Xiangtan Wastewater Treatment Plant in Hunan Province. The main character of the sludge included moisture content $76 \%, \mathrm{pH}$ value 6.8 , and volatile suspended solids $45.8 \%$. About $10 \mathrm{~kg}$ fresh sludge was dried in a freeze drier at $105^{\circ} \mathrm{C}$ again to a constant weight, then ground and sieved (100 mesh). The fresh sludge adsorbent appeared in the form of fine powder and was stocked before use. According to the literature [14], the other $10 \mathrm{~kg}$ sludge was fermented in the conditions of aerobic ventilation for 35 days. Then, as in previous examples, the humus sludge sorbent appeared and was stocked in a desiccator before use. According to reference [12], $50 \mathrm{~g}$ humus fine powder was added to $500 \mathrm{ml}$ and $1 \mathrm{~mol} \mathrm{~L}^{-1} \mathrm{FeCl}_{3}$ solution. Under continuous shaking at $100 \mathrm{rpm}$ for $24 \mathrm{~h}$, the humus fine powder was collected and washed repeatedly by deionized water until no $\mathrm{Fe}(\mathrm{III})$ ions were detected in the supernatant. The suspension was filtrated and dried in a freeze drier at $80^{\circ} \mathrm{C}$ again to a constant weight. The FTHSA appeared in the form of fine powder and was stocked in a desiccator before use.

\section{Chemicals}

Potassium antimony tartrate (purity $>99.9 \%$ ), $\mathrm{NaBH}_{4}$, $\mathrm{NaOH}, \mathrm{KI}$, ascorbic acid, etc., with a purity of $99.0 \%$ were purchased from Flying Boat Chemical Reagents Technology Co. Ltd. Tianjin, China. $\mathrm{HCl}$ purchased from Beijing Chemical Industry Co., Ltd, was excellent grade pure. The experimental water was taken from Synergy UV Millipore water (Millipore, USA). Configured $\mathrm{Sb}$ (III) aqueous solutions of $25 \mathrm{mg} \mathrm{L}^{-1}$ concentrations were stored in a refrigerator at $4^{\circ} \mathrm{C}$.

\section{Batch Sorption Procedure}

Sorption experiments were performed by batch equilibrium method. Some FTHSA was mixed with $250 \mathrm{ml}$ of $25 \mathrm{mg} \mathrm{L}^{-1} \mathrm{Sb}$ (III) solution at $25^{\circ} \mathrm{C}$. Upon reaching the adsorption equilibrium, the formed suspension was continuously stirred at the stirring rate of $3000 \mathrm{rpm}$ for 5 mins. The above supernatant was then filtered with a $0.45 \mu \mathrm{m}$ pore-size cellulose acetate membrane filter. Some part of filtrated aliquot was used to analyze the residual $\mathrm{Sb}$ (III) concentrations. The other was used to determine the final $\mathrm{pH}$. All experiments were performed in triplicate. The adsorption experiment was carried out under sealed light conditions.

At the conditions of $\mathrm{pH} 6.0$, dosage of $4.2 \mathrm{~g} \mathrm{~L}^{-1}$, reaction time of $120 \mathrm{~min}$, and $\mathrm{Sb}$ (III) initial concentration of $25 \mathrm{mg} \mathrm{L}^{-1}$, the experiments were carried out to investigate the adsorption differences of sludge adsorbents, humus sludge adsorbents, and FTHSA. Then, the effects of $\mathrm{pH}(1 \sim 6)$, adsorbent dosage (1 $\left.\sim 6 \mathrm{~g} \mathrm{~L}^{-1}\right), \mathrm{Sb}(\mathrm{III})$ initial concentration $\left(10 \sim 450 \mathrm{mg} \mathrm{L}^{-1}\right)$, 
and temperature $\left(10 \sim 30^{\circ} \mathrm{C}\right)$ on the removal of antimony by FTHSA were investigated by a single factor test. The isothermal adsorption experiment was carried out at $\mathrm{pH}=2$ and the adsorption isotherm concentration range was $10.0 \sim 450.0 \mathrm{mg} \mathrm{L}^{-1}$. The adsorption kinetics experiments lasted $400 \mathrm{~min}$, and sampling at different time intervals to analyze the concentration of supernatant concentration $\mathrm{Sb}$ (III). [12]:

The adsorption removal rate is calculated as follows

$$
\operatorname{Biosorption}(\%)=\frac{C_{i}-C_{f}}{C_{i}} \times 100 \%
$$

...where $\mathrm{C}_{\mathrm{i}}$ and $\mathrm{C}_{\mathrm{f}}\left(\mathrm{mg} \mathrm{L}^{-1}\right)$ are the initial and equilibrium concentrations of $\mathrm{Sb}$ (III) in solution, respectively.

\section{Characterization and Analytical Methods}

The concentration of $\mathrm{Sb}(\mathrm{III})$ in the experiment was determined by an AFS-9700atomic fluorescence spectrophotometer. Separating $\mathrm{Sb}(\mathrm{III})$ and $\mathrm{Sb}(\mathrm{V})$ with a strong anion exchange column (PRP X100), the ammonium tartrate $\left(200.0 \mathrm{mmol} \mathrm{L}^{-1}, \mathrm{pH} 5\right)$ was liquid. The system can do morphological analysis with $\mathrm{Sb}(\mathrm{III})$ and $\mathrm{Sb}(\mathrm{V})$ while achieving detection. The sample was tested at the same time as a blank test to replace the sample with deionized water. The recycling of $\mathrm{Sb}(\mathrm{III})$ was calculated to be $90.0 \%-99.5 \%$. Sb(V) was not detected, implying that $\mathrm{Sb}$ (III) did not trigger an oxidation reaction during the adsorption process.

The interface interactions of humus sludge sorbent, and FTHSA and FTHSA adsorption of Sb(III) were investigated using SEM-EDS and FT-IR. All of the lyophilized samples were sprayed with gold and analyzed by SEM (JSM-6380LV, Japanese electronics company) coupled with EDS spectroscopy (Bruker XFlash 5010, Germany). The FT-IR spectra were investigated using a Niclet 6700 spectrometer.

\section{Results and Discussion}

\section{Effect of Sludge Types}

As shown in Fig. 1, the highlighted variation of the adsorbed onto three adsorbents with the adsorption removal rate of $\mathrm{Sb}$ (III) $47.72 \%, 63.21 \%$, and $86.51 \%$, respectively. The results indicated that both humus treatment and Fe(III)-modification could improve the adsorptive removal of $\mathrm{Sb}(\mathrm{III})$. Compared with humus sludge, the FTHSA presented better adsorption performance. This was consistent with the experimental results by $\mathrm{Wu}$ et al. [10]. According to the modification data (data not shown), $1 \mathrm{~mol} \mathrm{~L}^{-1} \mathrm{Fe}$ (III) was selected as an optimal pretreatment.

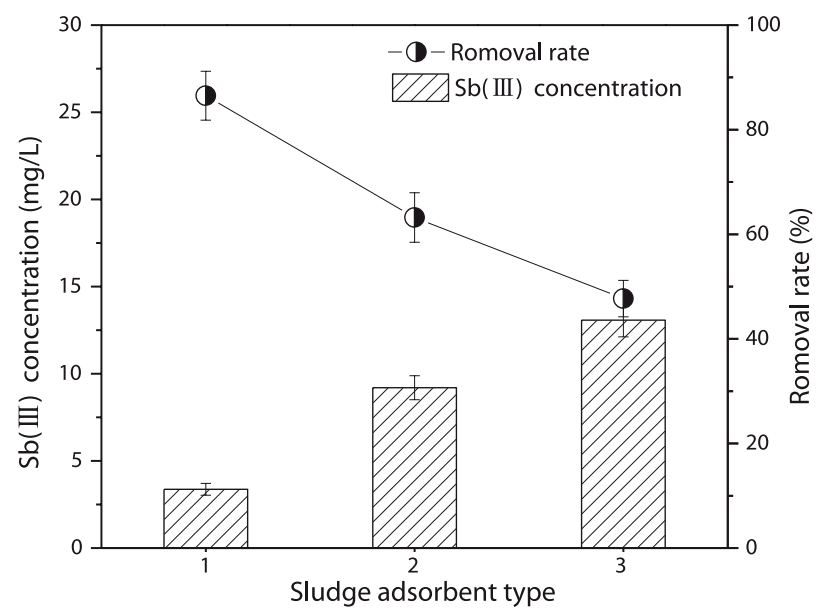

Fig. 1. Effect of Sludge types (1: FTHSA, 2: humus sludge, 3: Fresh sludge) on the removal rate of $\mathrm{Sb}(\mathrm{III})$ ions.

\section{Effect of $\mathrm{pH}$}

Effects of $\mathrm{pH}$ on the removal rate of $\mathrm{Sb}$ (III) ions by FTHSA are displayed in Fig. 2. At $\mathrm{pH}$ in the range of $1 \sim 6$, the removal rate increased first and then decreased, and the highest removal rate of $89.00 \%$ was reached at $\mathrm{pH}=2$. The removal rate displayed no significant changes with $\mathrm{pH}$ in the range of $2 \sim 4$, which is close to the other observed results by Kumar B, et al. [12, 19]. But it's less than the acidity coefficient pKa (3.6) of antimony potassium tartrate, which may be related to $\mathrm{Fe}(\mathrm{III})$-modification. The presence of $\mathrm{Sb}$ in solution is very complex and closely related to $\mathrm{pH}$ value. When $\mathrm{pH}<2, \mathrm{Sb}$ (III) is mainly cationic $\mathrm{Sb}(\mathrm{OH})^{2+}$, in the range of 2 10.7, it is mainly composed of $\mathrm{H}_{3} \mathrm{SbO}_{3}$ [4]. According to the calculating software Visual MINTEQ, at $20^{\circ} \mathrm{C}$ antimony potassium tartrate exists in a variety of forms. With $\mathrm{pH}$ of $2 \sim 3$, in the form of $\mathrm{Sb}(\mathrm{OH})_{3}$ it accounted for



Fig. 2. Effects of $\mathrm{pH}$ on the removal rate of $\mathrm{Sb}(\mathrm{III})$ ions by FTHSA: Initial concentration of $\mathrm{Sb}(\mathrm{III})=25 \mathrm{mg} \mathrm{L}^{-1}$, contact time $=120 \mathrm{~min}$, temperature $=20^{\circ} \mathrm{C}$, dosage of sorbent $=4.2 \mathrm{~g} \mathrm{~L}^{-1}$, and volume of solution $=250 \mathrm{~mL}$. 


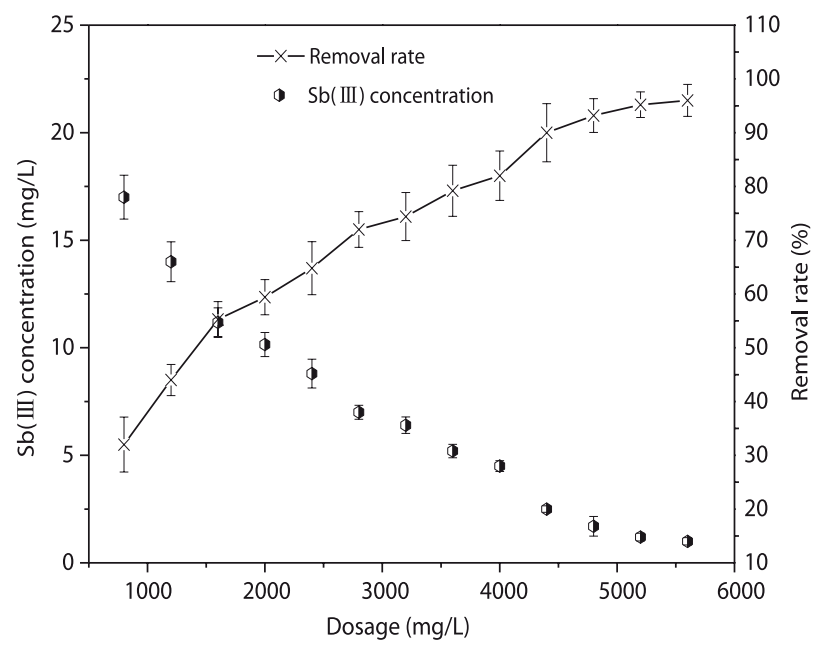

Fig. 3. Effects of dosage on the removal rate of $\mathrm{Sb}$ (III) ions by FTHSA: $\mathrm{pH}=5$, initial concentration of $\mathrm{Sb}$ (III) $=25 \mathrm{mg} \mathrm{L}^{-1}$, contact time $=60 \mathrm{~min}$, temperature $=20^{\circ} \mathrm{C}$, volume of solution $=250 \mathrm{~mL}$.

$75 \% \sim 80.0 \%$, the rest is the $\mathrm{Sb}(\mathrm{OH})^{2+}$ or $\mathrm{SbO}^{+}$[20]. And with $\mathrm{pH}$ of $4 \sim 7, \mathrm{Sb}(\mathrm{OH})_{3}$ accounts for $99.0 \%$ or more. When $\mathrm{pH}<2, \mathrm{H}^{+}$will completely combine with $\mathrm{Sb}(\mathrm{OH})^{2+}$ for adsorption sites, and the increase of $\mathrm{pH}$ will inhibit the formation of Fe(III) hydroxyl iron oxide and the solubility of iron ion, which will reduce the adsorption removal effect of $\mathrm{Sb}(\mathrm{III})$. Therefore, $\mathrm{pH}$ is one of the most important parameters affecting the $\mathrm{Sb}(\mathrm{III})$ ion adsorption process [21]. In this study, the best adsorption effect has been achieved at $\mathrm{pH}=2$.

\section{Effect of Dosage}

Fig. 3 shows the variations of $\mathrm{Sb}(\mathrm{III})$ removal rate under different dosages of FTHSA. The removal rate of $\mathrm{Sb}$ (III) increased linearly to $93.2 \%$ with the dosage increasing from $1000 \mathrm{mg} \mathrm{L}^{-1}$ to $4800 \mathrm{mg} \mathrm{L}^{-1}$, and slowly increased to $96.0 \%$ with the dosage increasing to $5600 \mathrm{mg}$ $\mathrm{L}^{-1}$. This indicates that the removal rate is not significantly elevated when the dosage of FTHSA is over $4800 \mathrm{mg} \mathrm{L}^{-1}$. This was absolutely consistent with other observations by Sun, et al. [22-23]. It was reported that the adsorbent surface provided more functional groups and adsorption sites with the increasing dosage, and the removal rate increased. On the other hand, the removal rate is to remain within a stable range and is no longer elevated when desorption has achieved dynamic equilibrium. So, taking into account costs and removal efficiency, the best dosage of FTHSA should be $4800 \mathrm{mg} \mathrm{L}^{-1}$.

\section{Effects of Initial Concentration}

As Shown in Fig. 4, excellent $\mathrm{Sb}(\mathrm{III})$ removal was achieved when the initial concentration of $\mathrm{Sb}$ (III) is within $5 \sim 50 \mathrm{mg} \mathrm{L}^{-1}$, with the removal efficiency between $99.0 \%$ to $97.5 \%$. Moreover, the concentration of $\mathrm{Sb}(\mathrm{III})$ in solution is below $0.05 \mathrm{mg} \mathrm{L}^{-1}$. However,

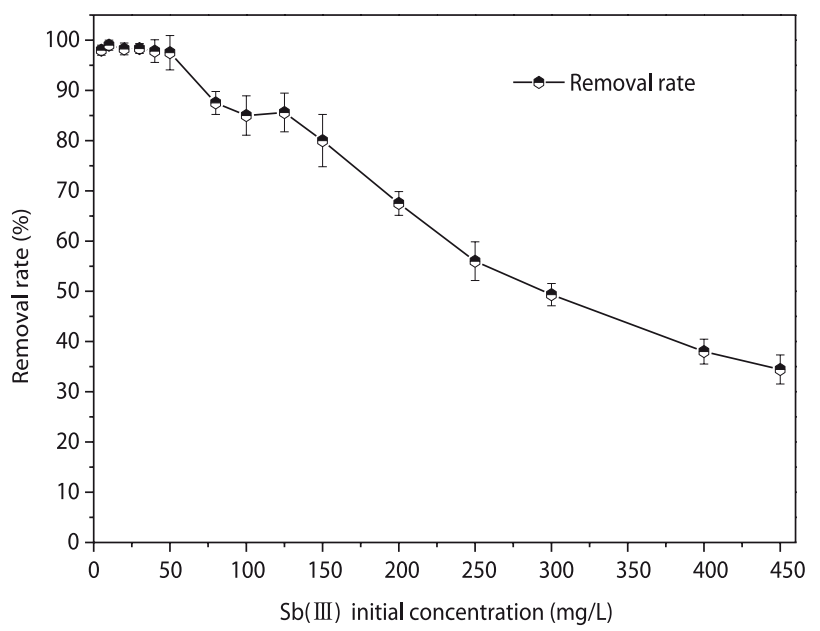

Fig. 4. Effects of initial concentration on the removal rate of $\mathrm{Sb}$ (III) ions by FTHSA: Contact time $=60 \mathrm{~min}, \mathrm{pH}=2$, temperature $=20^{\circ} \mathrm{C}$, dosage of sorbent $=4.2 \mathrm{~g} \mathrm{~L}^{-1}$, volume of solution $=250 \mathrm{~mL}$.

the removal efficiency decreased from $87.1 \%$ to $34.4 \%$ when the initial concentration of $\mathrm{Sb}$ (III) increased from $75 \mathrm{mg} \mathrm{L}^{-1}$ to $450 \mathrm{mg} \mathrm{L}^{-1}$. The removal efficiency decreased obviously. We deduced that FTHSA is wellsuited for treatment of low antimony wastewater in the range of $0 \sim 50 \mathrm{mg} \mathrm{L}^{-1}$.

\section{Effect of Temperature}

As shown in Fig. 5, the removal rate of FTHSA for $\mathrm{Sb}$ (III) ions decreased with the increasing temperature. Removal rate of FTHSA for $\mathrm{Sb}(\mathrm{III})$ ions at 283.15, 293.15, and $303.15 \mathrm{~K}$ were found to be $95.3 \%, 93.3 \%$, and $91.6 \%$, respectively. The results showed that removal efficiency was slightly decreased with the increasing temperature. So the temperature has little impact on the removal of

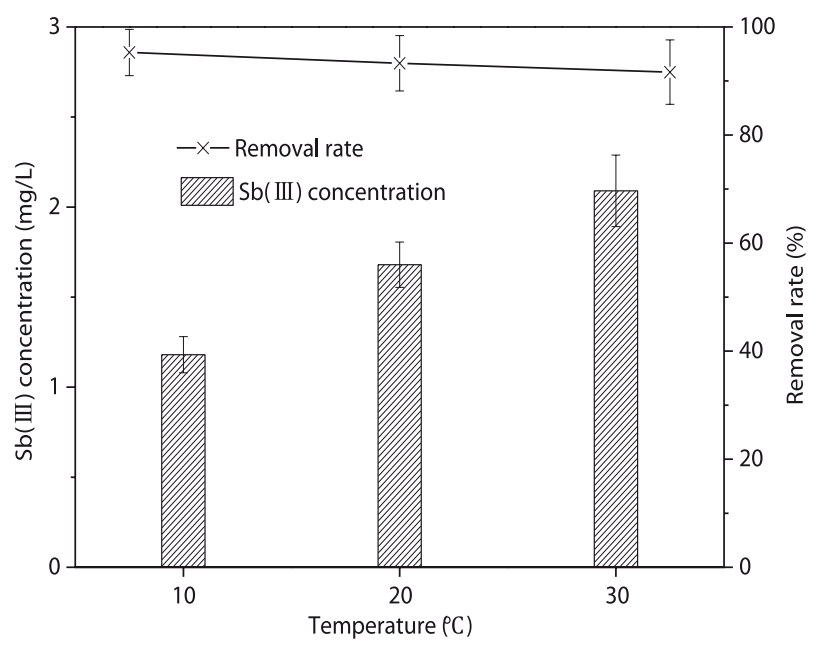

Fig. 5. Effects of temperature on the removal rate of $\mathrm{Sb}$ (III) ions by FTHSA: contact time $=120 \mathrm{~min}, \mathrm{pH}=2$, dosage of sorbent $=4.2 \mathrm{~g} \mathrm{~L}^{-1}$, volume of solution $=250 \mathrm{~mL}$, initial concentration of $\mathrm{Sb}(\mathrm{III})=25 \mathrm{mg} \mathrm{L}^{-1}$ 
$\mathrm{Sb}$ (III) from aqueous solution onto FTHSA. Fan et al. [24] got the same results when they treated the antimony wastewater by other sorbents. Moreover, the changing trend of removal efficiency under different temperatures implied that adsorbent of $\mathrm{Sb}$ (III) from aqueous solution onto FTHSA belongs to exothermic reaction.

\section{Adsorption Isotherm}

In this study, the adsorption isotherm study was carried out using Langmuir, Freundlich, and DubininRadushkevich (D-R) isotherm [25]. The applicability of the isotherm models to the adsorption study data was compared by judging the correlation coefficient $\left(\mathrm{R}^{2}\right)$ value [25].

\section{Langmuir Isotherm Model}

The Langmuir adsorption isothermal model describes a valid monolayer adsorption process, which assumes that all the adsorption sites have equal solute affinity and that adsorption at one site does not affect the adsorption at adsorbed molecules or an adjacent site [25]. It is expressed as follows:

$$
q_{e}=\frac{q_{\max } b C_{e}}{\left(1+b C_{e}\right)}
$$

...where $q_{e}\left(\mathrm{mg} \mathrm{g}^{-1}\right)$ is the amount of the $\mathrm{Sb}(\mathrm{III})$ in solid phase, $q_{\max }\left(\mathrm{mg} \mathrm{g}^{-1}\right)$ is the maximum adsorption capacity, $b\left(\mathrm{~L} \mathrm{mg}^{-1}\right)$ is the Langmuir equilibrium constant (the greater the value, the stronger the adsorption performance of the adsorbent), and $C_{e}\left(\mathrm{mg} \mathrm{L} \mathrm{L}^{-1}\right)$ is the equilibrium concentration of $\mathrm{Sb}$ (III) in the solution.

The linear plot of $C_{e} / q_{e}$ vs. $C_{e}$ is shown in Fig. 1a). The values of the constants $q_{\max }$ and $b$ are listed in Table 1. The $\mathrm{q}_{\max }$ values of $9.433 \mathrm{mg} \mathrm{g}^{-1}$ reflected that the maximum adsorption amount of FTHSA is bigger than cyanobacteria (4.88 $\left.\mathrm{mg} \mathrm{g}^{-1}\right)$ [10], seaweed $\left(4.0 \mathrm{mg} \mathrm{g}^{-1}\right)$ [11], but is much smaller than Lichens $\left(81.1 \mathrm{mg} \mathrm{g}^{-1}\right)$ [9]. The $b$ values of $0.119 \mathrm{~L} \mathrm{mg}^{-1}$ reflected that the adsorption performance is stronger than $\mathrm{Fe}(\mathrm{III})$-treated fungi aerobic granules $\left(0.112 \mathrm{~L} \mathrm{mg}^{-1}\right)$ [26], and weaker than ferric hydroxide $\left(0.275 \mathrm{~L} \mathrm{mg}^{-1}\right)$ [27]. In all, FTHSA has a high adsorption amount.

\section{Freundlich Isotherm Model}

The Freundlich adsorption isothermal model is applicable to both monolayer reversible adsorption and multilayer adsorption. It is given as Eq. (2).

$$
q_{e}=K_{f} C_{e}^{1 / n}
$$

... where $C_{e}$ is the equilibrium concentration of $\mathrm{Sb}$ (III) in solution $\left(\mathrm{mg} \mathrm{L}^{-1}\right)$, and $K_{f}$ and $1 / n$ are the Freundlich isotherm parameters that describe adsorption capacity and adsorption intensity, respectively.
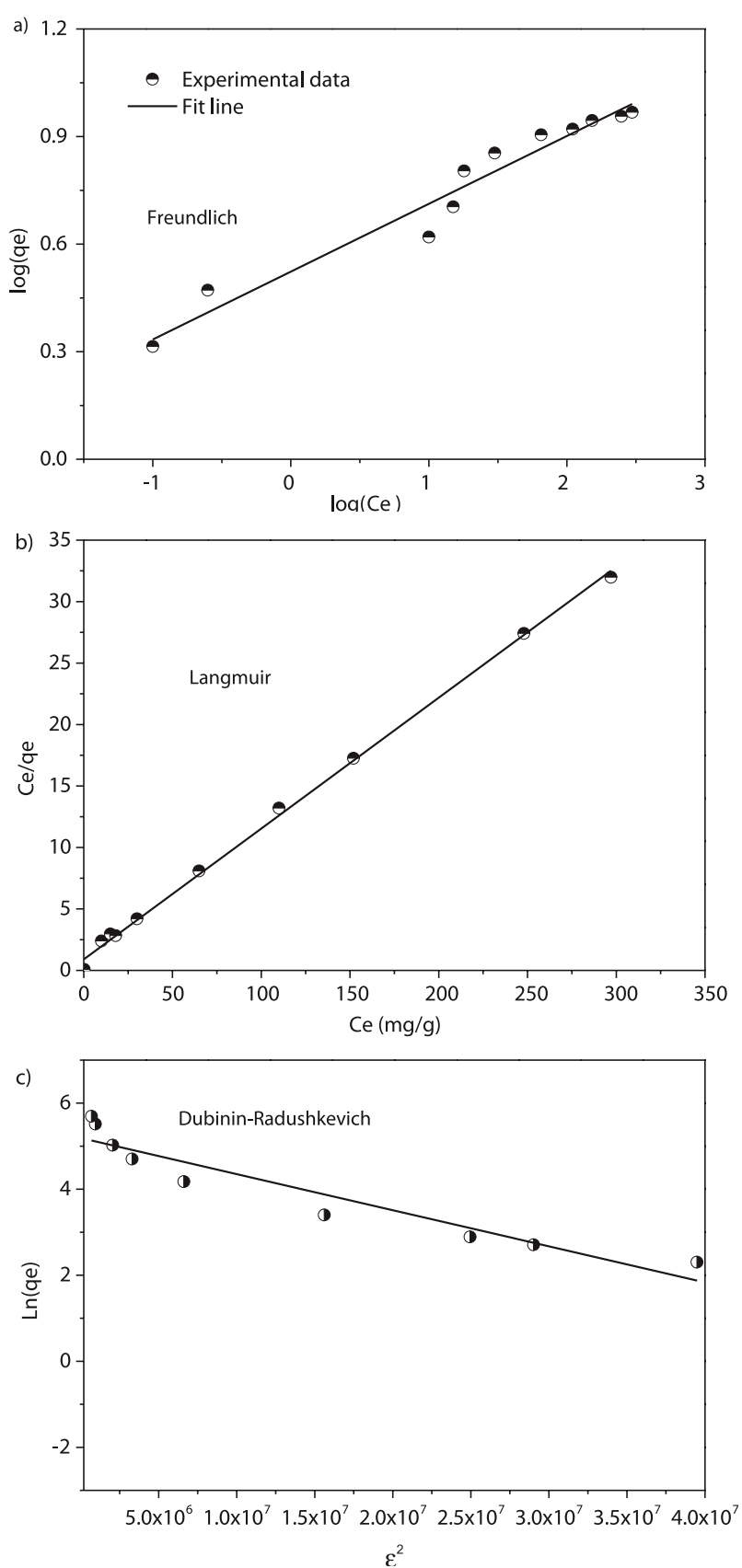

Fig. 6. Plots of adsorption isotherm model for the equilibrium date of $\mathrm{Sb}$ (III) adsorption onto FTHSA at $20^{\circ} \mathrm{C}$ : a) Langmuir, b) Freundlich, and c) D-R isotherms.

The values of $K_{f}$ and $1 / n$ can be determined experimentally by plotting $\log q_{e}$ versus $\log C_{e}$. As shown in Table $1, K_{f}$ and $1 / n$ were 3.336 and 0.189 , respectively. The values of $1 / n$ are much smaller than 0.5 , implying a close relation between adsorbate and adsorbent. It is concluded that the adsorbate can be easily adsorbed when the value of $1 / n$ is between 0.1 and 0.5 , while it is difficult to be adsorbed when the value of $1 / n$ is over 2.0 [28]. The value of $R^{2}\left(R^{2}>0.96\right)$, Freundlich models were fit well the adsorption of $\mathrm{Sb}$ (III), which implied that there was both electrostatic interaction and ion exchange during the adsorption process. SEM characterization also 
Table 1. Isotherm parameters for the adsorption of Sb(III) onto FTHSA.

\begin{tabular}{|c|c|c|c|}
\hline \multirow{4}{*}{ Models } & Langmuir & Freundlich & $\mathrm{D}-\mathrm{R}$ \\
\hline \multirow{4}{*}{ Parameters } & $q_{\max }=9.433 \mathrm{mg} \mathrm{g}^{-1}$ & $K_{f}=3.336$ & $\beta=-8.39 \mathrm{E}^{-8} \mathrm{~mol}^{2} / \mathrm{KJ}^{2}$ \\
\cline { 2 - 4 } & $b=0.119 \mathrm{~L} \mathrm{mg}^{-1}$ & $1 / n=0.189$ & $q_{s}=179.45 \mathrm{mg} \mathrm{g}^{-1}$ \\
\cline { 2 - 4 } & -- & -- & $E=24.1 \mathrm{~mol} \mathrm{KJ}^{-1}$ \\
\cline { 2 - 4 } & $R^{2}=0.9977$ & $R^{2}=0.9636$ & $R^{2}=0.8940$ \\
\hline
\end{tabular}

further confirmed that these materials had a larger hole volume size and smaller aperture.

\section{Dubinin-Radushkevich Model}

The D-R isotherm model is more widely used than the Langmuir isotherm or Freundlich isothermal, because it does not assume a homogeneous surface or constant adsorption potential [25]. It may be expressed as:

$$
\operatorname{Ln}\left(q_{e}\right)=\operatorname{Ln}\left(q_{s}\right)-\beta \varepsilon^{2}
$$

...where $\beta$ is the $\mathrm{D}-\mathrm{R}$ isotherm constant $\left(\mathrm{mol}^{2} \mathrm{~kJ}^{-2}\right), q_{s}$ is the theoretical isotherm saturation capacity $\left(\mathrm{mg} \mathrm{g}^{-1}\right)$, and $\varepsilon$ is the Polanyi potential - calculated as follows:

$$
\varepsilon=R \operatorname{Tln}\left(1+1 / C_{e}\right)
$$

...where $R$ is universal gas constant, $8.314 \mathrm{Jmol}^{-1} \mathrm{~K}^{-1} ; T$ is the absolute temperature $(293.15 \mathrm{~K})$; and $C_{e}\left(\mathrm{~mol} \mathrm{~L}^{-1}\right)$ is the concentration of $\mathrm{Sb}(\mathrm{III})$ in equilibrium solution.

The experimental data of D-R model had been analyzed by linear method from the plot of $\ln q_{e}$ vs. $\varepsilon^{2}$. As shown in Fig. 6c) and Table 1, the plot of $\ln q_{e}$ vs. $\varepsilon^{2}$ gives a straight line with the $R^{2}$ of 0.8940 , and the values of $q_{s}$ and $\beta$ are $8.39 \mathrm{E}^{-8} \mathrm{~mol}^{2} \mathrm{KJ}^{-2}$ and $179.45 \mathrm{mg} \mathrm{g}^{-1}$, respectively, which are determined from the intercept and slope using the linear regression method. Parameter $\beta$ offers noteworthy information about the mean adsorption energy, which is the free energy change when one mole of ion is transferred to the surface of the sorbents from the solution [29]. It is calculated by Eq. (5):

$$
E=(-2 \beta)^{-1 / 2}
$$

The value of $E$ is useful for estimating the type of adsorption process [28]. According to the nature of the forces existing between the adsorbate and sorbent, the adsorption process can be classified as physical adsorption (1-8 $\left.\mathrm{KJ} \mathrm{mol}^{-1}\right)$, ion exchange (9-16 $\left.\mathrm{KJ} \mathrm{mol}^{-1}\right)$, and chemical adsorption $\left(>16 \mathrm{KJ} \mathrm{mol}^{-1}\right)$ [30]. The value of $E$ in this study was found to be $24.1 \mathrm{~mol} \mathrm{KJ}^{-1}$ (Table 1), indicating that the adsorption mechanism of $\mathrm{Sb}(\mathrm{III})$ onto FTHSA is chemical adsorption [29-30].

In conclusion, Langmuir isotherm parameters fit quite well with the experimental data for $\mathrm{Sb}(\mathrm{III})$ adsorption on FTHSA and yielded isotherms that agreed well with the observed behavior $\left(\mathrm{R}^{2}>0.99\right)$, indicating a monolayer adsorption process [28]. The adsorption capacity of $\mathrm{Sb}$ (III) on FTHSA at $293.15 \mathrm{~K}$ from Langmuir model was $9.433 \mathrm{mg} \mathrm{g}^{-1}$. D-R isotherm further supported that the adsorption $\mathrm{Sb}$ (III) on FTHSA was a chemical sorption process.

\section{Adsorption Kinetics}

As everyone knows, adsorption kinetics are dominated by physical and chemical characteristics of the adsorbent during the mass migration process [31]. In order to investigate the kinetic characteristics of the adsorption process of $\mathrm{Sb}$ (III) ions onto FTHSA from aqueous solution, pseudo first-order, pseudosecondorder, Elovich [32], and intraparticle diffusion [31] kinetic models are used to fit the experimental data.

\section{Pseudo First-Order Model}

The pseudo first-order equation based on solid adsorption capacity is the most common and may be written as Eq. (6) [32]:

$$
q_{t}=q_{e}\left(1-\exp \left(-k_{1} t\right)\right)
$$

...where $k_{l}\left(\mathrm{~min}^{-1}\right)$ is the pseudo first-order adsorption rate constant, and $q_{t}$ and $q_{e}\left(\mathrm{mg} \mathrm{g}^{-1}\right)$ are the adsorption capacities at time $t(\mathrm{~min})$ and at equilibrium, respectively.

As shown in Fig. 7a) and Table 2, the plot fitted the experimental data, and the calculated value of $q_{e}$ $\left(9.340 \mathrm{mg} \mathrm{g}^{-1}\right)$ is very consistent with the experimental value of $q_{e}\left(9.433 \mathrm{mg} \mathrm{g}^{-1}\right)$. So it implies that the adsorption process of $\mathrm{Sb}$ (III) ions onto FTHSA can well be described by the pseudo first-order model.

\section{Pseudo Second-Order Model}

The pseudo second-order kinetic model assumes that the adsorption rate is controlled by the chemical adsorption mechanism, which involves electron sharing or electron transfer between the adsorbent and the adsorbate. It is described as Eq. (7).

$$
q_{t}=q_{e}-q_{e} /\left(k_{2} q_{e} t+1\right)
$$


Table 2. Calculated kinetic parameters for the adsorption of Sb(III) onto FTHSA.

\begin{tabular}{|c|c|c|c|c|c|}
\hline Models & $\begin{array}{l}\text { Pseudo first } \\
\text {-order model }\end{array}$ & $\begin{array}{l}\text { Pseudo second } \\
\text {-order model }\end{array}$ & Elovich model & \multicolumn{2}{|c|}{ Intraparticle diffusion model } \\
\hline Equation & $\mathrm{q}_{\mathrm{t}}=\mathrm{q}_{\mathrm{e}}\left(1-\exp \left(-\mathrm{k}_{1} \mathrm{t}\right)\right)$ & $\mathrm{q}_{\mathrm{t}}=\mathrm{q}_{\mathrm{e}}-\left(\mathrm{q}_{\mathrm{e}} /\left(\mathrm{k}_{2} \mathrm{q}_{\mathrm{e}} \mathrm{t}+1\right)\right.$ & $\mathrm{q}_{\mathrm{t}}=\ln (\beta \alpha) / \beta+(1 / \beta) \ln t$ & \multicolumn{2}{|c|}{$\mathrm{q}_{\mathrm{t}}=\alpha_{\mathrm{i}}+\mathrm{k}_{4 \mathrm{i}} \mathrm{t}^{0.5}$} \\
\hline \multirow{3}{*}{ Parameters } & $\mathrm{q}_{\mathrm{e}}=9.340 \mathrm{mg} \mathrm{g}^{-1}$ & $\mathrm{q}_{\mathrm{e}}=10.185 \mathrm{mg} \mathrm{g}^{-1}$ & $\alpha=2.026 \mathrm{mg} \mathrm{mg}^{-1} \mathrm{~min}^{-1}$ & $\alpha_{1}=0.381 \mathrm{mg} \mathrm{g}^{-1}$ & $\alpha_{2}=8.595 \mathrm{mg} \mathrm{g}^{-1}$ \\
\hline & $\mathrm{k}_{1}=0.0616 \mathrm{~min}^{-1}$ & $\begin{array}{c}\mathrm{k}_{2}=\underset{\mathrm{min}^{-1}}{-0.088 \mathrm{~g} \mathrm{mg}^{-1}} \\
\end{array}$ & $\beta=0.883 \mathrm{~g} \mathrm{mg}^{-1}$ & $\mathrm{k}_{41}=1.262 \mathrm{mg} \cdot \mathrm{g}^{-1} \cdot \mathrm{min}^{-0.5}$ & $\begin{array}{c}\mathrm{k}_{42}=0 . .058 \mathrm{mg} \cdot \mathrm{g}^{-1} . \\
\min ^{-0.5}\end{array}$ \\
\hline & $\mathrm{R}^{2}=0.992$ & $\mathrm{R}^{2}=0.993$ & $\mathrm{R}^{2}=0.872$ & $\mathrm{R}_{1}^{2}=0.972$ & $\mathrm{R}_{2}^{2}=0.923$ \\
\hline
\end{tabular}

...where $k_{2}\left(\mathrm{~g} \mathrm{mg}^{-1} \mathrm{~min}^{-1}\right)$ is the pseudo second-order adsorption rate constant, and $q_{e}$ and $q_{t}\left(\mathrm{mg} \mathrm{g}^{-1}\right)$ are $\mathrm{Sb}$ (III) adsorption capacity at equilibrium and at time $\mathrm{t}$ ( $\mathrm{min}$ ), respectively.

The fitting curve of $q_{t}$ vs. $\mathrm{t}$ is plotted in Fig. 7a) and is used to obtain the calculated pseudo second-order parameters and correlation coefficient. The values of theoretical $q_{e}\left(10.185 \mathrm{mg} \mathrm{g}^{-1}\right.$, Table 2$)$ and experimental $q_{e}\left(9.433 \mathrm{mg} \mathrm{g}^{-1}\right)$ are approximately equal to each other, and the correlation coefficient $\left(R^{2}\right)$ is up to 0.993 , which reveals the adsorption of $\mathrm{Sb}(\mathrm{III})$ ions onto FTHSA following the pseudo second-order kinetic model [25, 28].

\section{Elovich Model}

The Elovich model primary has been used to describe the kinetics of the chemisorption of gases on solids. But the same researchers applied this model to describe chemisorption of adsorbate by a solid in an aqueous medium. This model is formulated with Eq. (8):

$$
q_{t}=\ln (\alpha \beta) / \beta+(1 / \beta) \ln t
$$

...where $q_{t}\left(\mathrm{mg} \mathrm{g}^{-1}\right)$ is $\mathrm{Sb}(\mathrm{III})$ adsorption capacity at time $t$ (min), $\alpha\left(\mathrm{mg} \mathrm{mg}^{-1} \mathrm{~min}^{-1}\right)$ is the sorption constant for $\mathrm{Sb}$ (III), and $\beta\left(\mathrm{g} \mathrm{mg}^{-1}\right)$ is related to surface coverage and chemical activation energy.

As seen from the Fig. 7c), the fitting curve does not converge well when the Elovich model was applied to the experimental data. But the sorption of $\mathrm{Sb}(\mathrm{III})$ onto FTHSA are examples of heterogeneous systems because the reactions involve component types that exhibit different chemisorption activation energies [25, 28].

\section{Intraparticle Diffusion model}

The intraparticle diffusion model describes the mechanism of diffusion between particles and the pores of the adsorbent. It is expressed with Eq. (9):

$$
q_{t}=a_{i}+k_{4 i} t^{0.5}
$$

...where $k_{4 i}\left(\mathrm{mg} \cdot \mathrm{g}^{-1} \mathrm{~min}^{-0.5}\right)$ is a rate constant of stage $i$, which is related to the thickness of the boundary layer, and $\alpha_{i}\left(\mathrm{mg} \mathrm{g}^{-1}\right)$ is an intraparticle diffusion model constant of stage $i$. Adsorption capacity $q_{t}$ versus $\mathrm{t}^{0.5}$ should be linear.
If the plot passes through the origin, the rate-limiting process may be from intraparticle diffusion. However, if the data presents multi-linear plots, two or more steps are contained in the adsorption process.

As seen from Fig. 7b), adsorption capacity $q_{t}$ vs. $t^{0.5}$ shows two stages that are strongly linear but different slopes. The first stage described the rapid external resistance to mass transfer surrounding the surface of adsorption particles. The second stage represented the
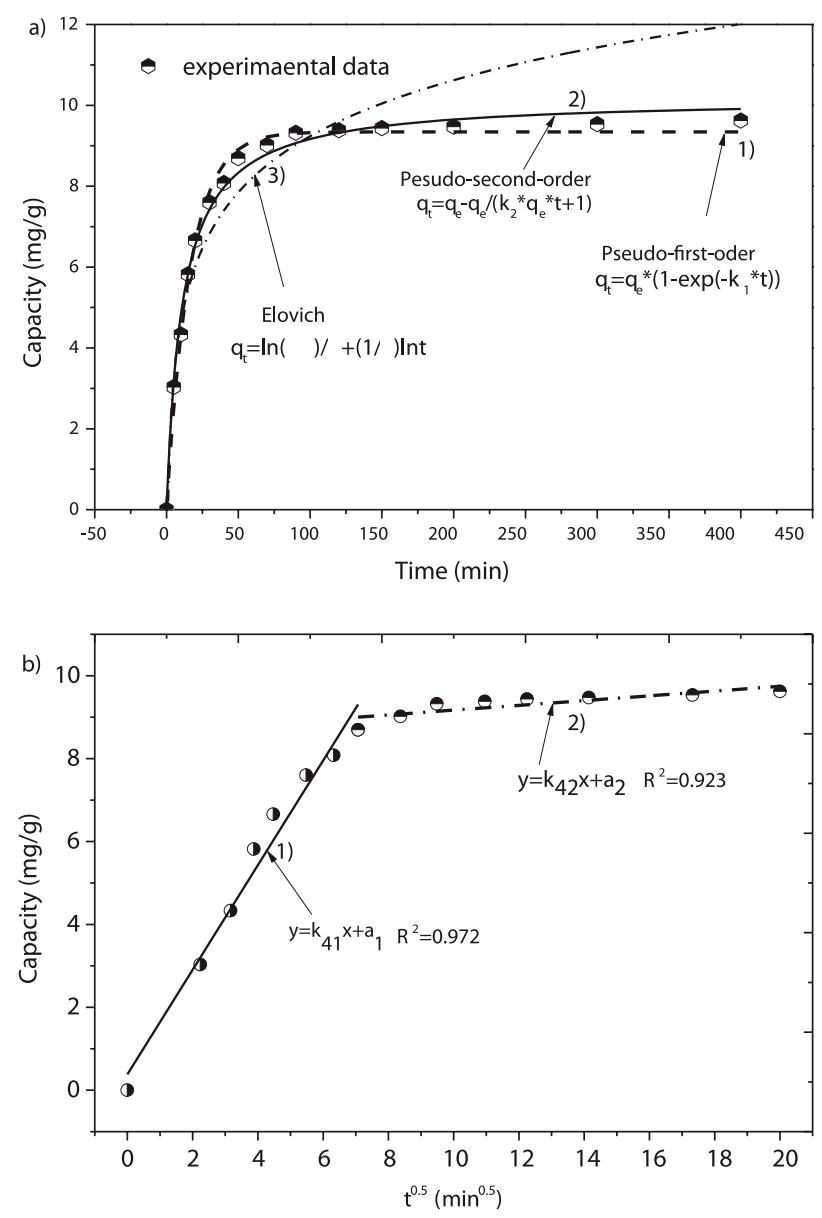

Fig. 7. Plots of pseudo first-order a), pseudo second-order b), Elovich c), and intra-particle diffusion d) models for the kinetic data of $\mathrm{Sb}(\mathrm{III})$ adsorption onto FTHSA: contact time $=120 \mathrm{~min}, \mathrm{pH}=2$, dosage of adsorbent $=4.2 \mathrm{~g} \mathrm{~L}^{-1}$, volume of solution $=250 \mathrm{~mL}$, initial concentration of $\mathrm{Sb}(\mathrm{III})=25 \mathrm{mg} \mathrm{L}^{-1}$, temperature $=30^{\circ} \mathrm{C}$. 
gradual absorption stage with the intraparticle diffusion dominating. The calculated intercept $\left(\alpha_{1}, \alpha_{2}\right)$ value are 0.381 and 8.595 , respectively, suggesting that the pore diffusion was not the sole rate-controlling step due to the difference in rate of mass transfer in the first and second stages of adsorption. These findings implied that the rate-dominating step of the adsorption process of $\mathrm{Sb}$ (III) onto FTHSA might be originated from boundary layer diffusion or external mass transfer effects [25, 28].

Comparing the results obtained from the above four models, the pseudo second-order model can best fit with
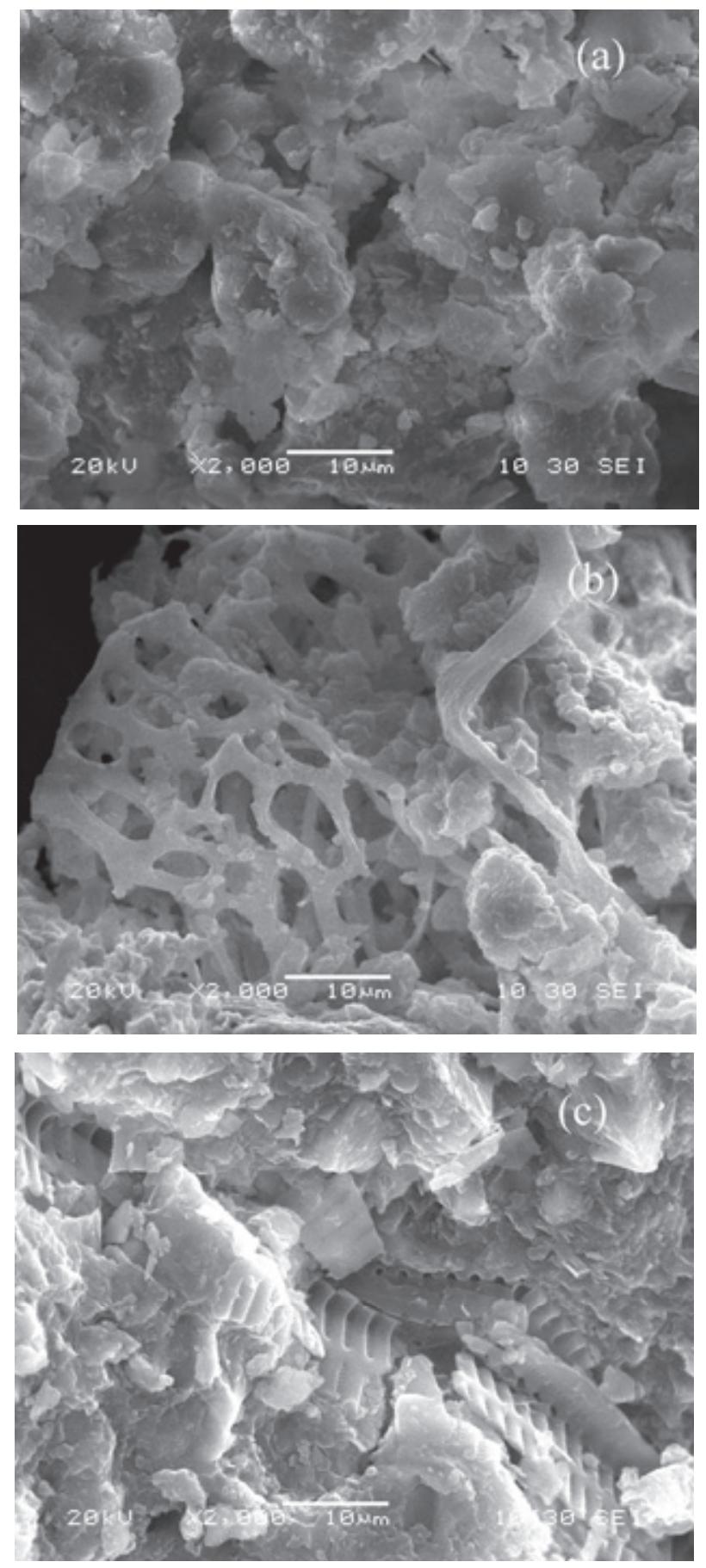

Fig. 8. SEM images of humus sludge sorbent derivatives: a) humus sludge sorbent, b) FTHSA, c) FTHSA with Sb(III).
FTHSA adsorption on Sb(III). The whole adsorption process of $\mathrm{Sb}(\mathrm{III})$ adsorption onto FTHSA was in conformity with the pseudo second-order kinetic model. It is possible to announce that the chemical adsorption on FTHSA surface plays a dominant role in the adsorption process [33], and that $\mathrm{Sb}$ (III) ions can combine with thiol groups of FTHSA through covalent chemical bonds.

\section{Adsorption Mechanisms}

\section{Morphology}

As shown in Fig. 8a), the morphology of humus sludge adsorbent was heterogeneous with few small bulges on the surface with EDS analysis. It contained $\mathrm{C}, \mathrm{O}, \mathrm{Al}, \mathrm{Si}$, $\mathrm{Ca}, \mathrm{Cl}, \mathrm{K}$, and $\mathrm{Fe}$ (Table 3), and $\mathrm{Sb}$ iron was not detected. After $\mathrm{Fe}(\mathrm{III})$ treatment, as expected, many pores were seen on the FTHSA surface (Fig. 8b), and the contents of Fe were 5.66 wt.\%, 8.2 times compared to the humus sludge adsorbent. Similar results also were found by Wang et al. [12] and M.J. Jimenez-Cedillo, et al. [34]. Moreover, the content of $\mathrm{K}$ was much smaller than before treatment, which implied that the $\mathrm{K}^{+}$was important for the modification of humus sludge adsorbent with an ion exchange effect [12]. After adsorption of $\mathrm{Sb}(\mathrm{III})$, the $\mathrm{Sb}$ content in FTHSA increased to $1.32 \mathrm{wt} . \%$, which implied that $\mathrm{Sb}$ (III) ions were adsorbed onto it.

The FT-IR spectra of the humus sludge adsorbent, FTHSA, and after sorption of $\mathrm{Sb}$ (III) are presented in Fig. 9. As shown in Fig. 9a), broad strong absorption bands observed at $3423 \mathrm{~cm}^{-1}$ corresponded to $\mathrm{O}-\mathrm{H}$ stretching vibration of the hydroxyl groups from the alcohols, and carboxylic acids or N-H stretching vibration. Four peaks at 2958, 2925, 2854, and $1401 \mathrm{~cm}^{-1}$ displayed the asymmetric stretching vibration, symmetric stretching vibration, bending vibration, and symmetric bending vibration of $-\mathrm{CH}_{2}$. The bends at 1654 and $1538 \mathrm{~cm}^{-1}$ display the $-\mathrm{C}=\mathrm{O}$ and $\mathrm{C}-\mathrm{N}$ stretching vibrations of amide I from peptide bonds in proteins and $\mathrm{C}-\mathrm{N}$ stretching vibration and $\mathrm{N}-\mathrm{H}$ deformation vibration of amide II from peptide bonds in proteins, respectively [12]. A weak band observed at $1079 \mathrm{~cm}^{-1}$ was $\mathrm{C}-\mathrm{O}$ stretching vibration and attributed to the presence of the alcohols or carboxylic acids [34]. The big peaks observed at $1036 \mathrm{~cm}^{-1}$ was $\mathrm{O}-\mathrm{H}$ stretching vibrations and were attributed to the presence of lots of polysaccharides [12]. Bands less than $1000 \mathrm{~cm}^{-1}$ are fingerprint spectrum, which provided the information of phosphoric acid group and sulfur-containing group [35].

The obvious changes of FTHSA in the FT-IR spectra were presented in Fig. 9b). FTHSA displayed a broader peak in the range of $3414 \mathrm{~cm}^{-1}$, which implied the presence of $\mathrm{O}-\mathrm{H}$ and $\mathrm{N}-\mathrm{H}$ functional groups on the surface. The bands in the range of $2960-2852 \mathrm{~cm}^{-1}$ were owed to the $\mathrm{C}-\mathrm{H}$ stretching vibration, which shifted in FTHSA. The peak at $1654 \mathrm{~cm}^{-1}$, which was assigned to the $\mathrm{C}=\mathrm{O}$ stretching vibration for the amide $\mathrm{I}$ band from EPS [36], moved to $1650 \mathrm{~cm}^{-1}$ in FTHSA. The band at $1036 \mathrm{~cm}^{-1}$ also shifted to $1040 \mathrm{~cm}^{-1}$ owing to the $\mathrm{O}-\mathrm{H}$ 
Table 3. Elemental composition of humus sludge sorbent, FTHSA, and FTHSA with Sb(III).

\begin{tabular}{|c|c|c|c|c|c|c|c|c|c|c|c|}
\hline \multicolumn{2}{|c|}{ Element } & C K & O K & Al K & Si K & Ca K & Cl K & K K & Fe L & Sb L & Total \\
\hline \multirow{4}{*}{$\begin{array}{c}\text { Composition } \\
\text { (Wt.\%) }\end{array}$} & Humus sludge sorbent & 32.68 & 17.98 & 9.85 & 16.82 & 4.41 & 13.45 & 4.12 & 0.69 & -- & 100 \\
\cline { 2 - 12 } & FTHSA & 32.52 & 17.03 & 9.41 & 16.81 & 4.03 & 13.74 & 0.8 & 5.66 & -- & 100 \\
\cline { 2 - 29 } & FTHSA with Sb(III) & 32.47 & 17.05 & 8.93 & 15.82 & 4.45 & 14.05 & 1.12 & 4.79 & 1.32 & 100 \\
\hline
\end{tabular}

stretching vibrations from polysaccharide, which implied that the polysaccharide played an important role in $\mathrm{Fe}$ treatment [12].

These results suggest that the functional groups were successfully changed by the Fe(III)-treatment. After the adsorption of Sb(III), FTHSA FT-IR spectra also changed significantly (Fig. 8c), with characteristic peak position changing to $3403,2926,1648,1546,1039$, and $534 \mathrm{~cm}^{-1}$. The peaks in the range of $3400-3430 \mathrm{~cm}^{-1}$ are due to the stretching vibrations of $\mathrm{N}-\mathrm{H}$ and $\mathrm{O}-\mathrm{H}$ bonds [36-37]. The movement of the absorption peak at $1648 \mathrm{~cm}^{-1}$ is assigned to the $\mathrm{C}=\mathrm{O}$ stretching vibration for the amide I band [36]. The weak peak at $1401 \mathrm{~cm}^{-1}$ corresponds to the $\mathrm{C}-\mathrm{O}$ stretching vibration in the phenolic hydroxyl groups and anti-symmetry stretching of COO. The strong peak at $1040 \mathrm{~cm}^{-1}$ is attributed to the $\mathrm{C}-\mathrm{O}$ stretching vibration. The movement of that position indicates that the $\mathrm{C}-\mathrm{O}$ bond from the humus reacts with the $\mathrm{Sb}$ (III). Additionally, the wave peak shifted from 536 to 534, which is ascribed to the stretching vibration of the $\mathrm{Sb}$ (III)-O [27]. These results indicate that the chemical interactions as ion exchange among the metal ions and $\mathrm{N}-\mathrm{H}, \mathrm{O}-\mathrm{H}, \mathrm{C}=\mathrm{O}, \mathrm{COO}$, and $\mathrm{C}-\mathrm{O}$ were mainly involved in the adsorption.

\section{Conclusions}

Adsorption behavior and mechanism of $\mathrm{Sb}(\mathrm{III})$ onto FTHSA surface under different conditions have been investigated. The adsorption of $\mathrm{Sb}$ (III) onto FTHSA were

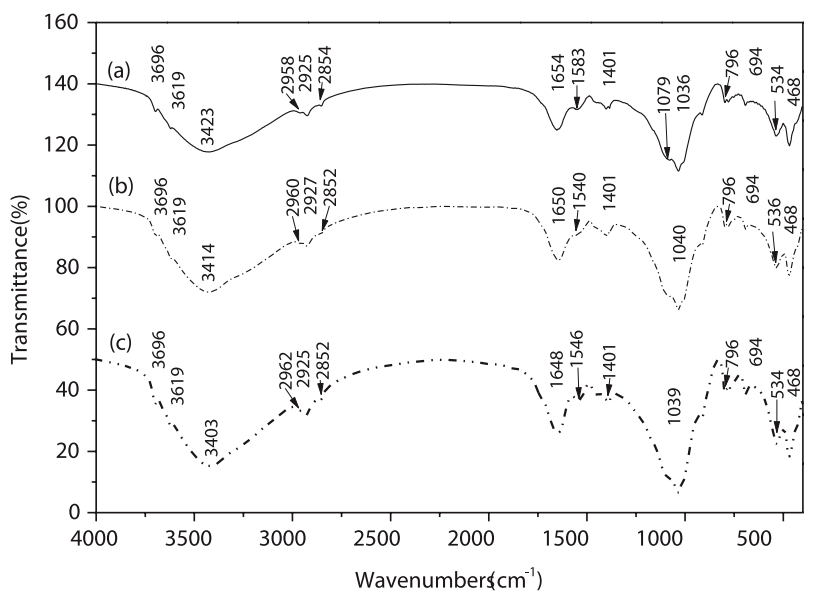

Fig. 9. FT-IR spectra of: a) humus sludge sorbent, b) FTHSA, c) FTHSA with $\mathrm{Sb}$ (III). affected by dosage, contact time, initial concentration of $\mathrm{Sb}$ (III), and $\mathrm{pH}$. And the value of maximum adsorption capacity of FTHSA was obtained as $9.433 \mathrm{mg} / \mathrm{g}$. The Langmuir model plot was the best fit to the experimental data of $\mathrm{Sb}$ (III) ions adsorption. The pseudo second-order model can best fit with FTHSA adsorption of $\mathrm{Sb}$ (III). This also suggested that the chemical adsorption on FTHSA surface played a dominant role in the adsorption process. The chemical interactions as ion exchange among the metal ions and $\mathrm{N}-\mathrm{H}, \mathrm{O}-\mathrm{H}, \mathrm{C}=\mathrm{O}, \mathrm{COO}$, and $\mathrm{C}-\mathrm{O}$ were mainly involved in the adsorption of $\mathrm{Sb}$ (III) onto FTHSA. The FTHSA may be an efficient and cheap sorbent for removal the $\mathrm{Sb}$ (III) from wastewater.

\section{Acknowledgements}

This study was financially supported by the National Natural Science Foundation of China (No. 41672350) and the National Natural Science Foundation of China, Hunan Province (No. 2016JJ6041).

\section{References}

1. JOHNSON C.A., MOENCH H., WERSIN P., KUGLER P., WENGER C. Solubility of antimony and other elements in samples taken from shooting ranges. Environmental Quality, 12 (34), 248, 2005.

2. NING Z.P., XIAO T.F. Supergene geochemical behavior and environmental risk of antimony. Earth and Environment, 35 (2), 176, 2004.

3. WU F.C., ZHENG J., PAN X.L., LI W. Prospect on Biogeochemical cycle and Environmental effect of antimony. Advances in Earth Science, 23 (4), 350-, 2008.

4. UNGUREANU G., SANTOS S., BOAVENTURA R., BOTELHO C. Arsenic and antimony in water and wastewater: overview of removal techniques with special reference to latest advances in adsorption. Journal of Environmental Management, 151 (1), 326, 2015.

5. INDIKA HERATH, METHTHIKA VITHANAGE, JOCHEN BUNDSCHUH Antimony as a global dilemma: Geochemistry, mobility, fate and transport. Environmental Pollution, 223, 545, 2017.

6. KANG M., KAMEI T., MAGARA Y. Comparing polyaluminum chloride and ferric chloride for antimony removal. Water Research, 37 (17), 4171, 2003.

7. ZHU J., WU F.C. Application of Modified Fly Ash in Treatment of Antimony Mineral Processing Wastewater. Journal of Environmental Science, 30 (2), 361, 2010.

8. ZHANG YAN, PANG ZHIHUA, LEI YUTAO Study on Influencing Factors and Kinetics of Antimony Ion 
Treatment by Coagulation and Sedimentation. Journal of Safety and Environment, 13 (3), 50-53, 2013.

9. ULUOZLU O.D., SARI A., TUZEN M. Biosorption of antimony from aqueous solution by lichen (Physcia tribacia) biomass. Chemical Engineering Journal, 163 (3), 382, 2010.

10. WU F., SUN F., WU S., YAN Y., XING B. Removal of antimony(III) from aqueous solution by freshwater cyanobacteria Microcystis biomass. Chemical Engineering Journal, 183, 172, 2012.

11. UNGUREANU G., SANTOS S.C.R., VOLF I., BOAVENTURA R.A.R., BOTELHO C.M.S. Biosorption of antimony oxyanions by brown seaweeds: Batch and column studies. Journal of Environmental Chemical Engineering, 5 (4), 3463, 2017.

12. LI WANG, CHUNLI WAN, DUU-JONG LEE, XIANG LIU, YI ZHANG, CHEN X.F., JOO-HWATAY Biosorption of antimony (V) onto $\mathrm{Fe}(\mathrm{III})$-treated aerobic granules. Bioresource Technology, 158 (2), 351, 2014.

13. CHUNLI WAN, LI WANG, DUU-JONG LEE, QINLAN ZHANG, JIENI LI, XIANG LIU Fungi aerobic granules and use of Fe(III)-treated granules for biosorption of Sb5+. Journal of the Taiwan Institute of Chemical Engineers, 45, 2610, 2014.

14. WANG XIAONING, ZHU NANWEN, YIN BINGKUI Preparation of sludge-based activated carbon and its application in dye wastewater treatment. Journal of Hazardous Materials, 153 (1/2), 227, 2008.

15. XIANG W.Y., ZHANG Z.M. Preparation of composite adsorbent with chitosan and activated sludge. Acta Scientiae Circumstantiae, 34 (11), 2792, 2014.

16. XUEHUA LI, XIAOMIN DOU, JUNQING LI Antimony(V) removal from water by iron-zirconium bimetal oxide:Performance and mechanism. Journal of Environmental Science, 24 (7), 1197, 2012.

17. ESPEN MARIUSSEN, IDA VAA JOHNSEN, STRØMSENG A.E. Selective adsorption of lead, copper and antimony in runoff waterfrom a small arms shooting range with a combination of charcoal and iron hydroxide. Journal of Environmental Management, 150, 281, 2015.

18. JIMÉNEZ-CEDILLO M.J., OLGUÍN M.T., FALL C., COLIN-CRUZ A. As(III) and As(V) sorption on ironmodified non-pyrolyzed and pyrolyzed biomass from Petroselinum crispum (parsley). Journal of Environmental Management, 117, 242, 2013.

19. KUMAR B.B., MOUE J., KAWAKITA HBK BISWAS, INOUE K. Effective removal and recovery of antimony using metal-loaded saponified orange waste. Hazardous Materials, 172 (2-3), 721, 2009.

20. WATKINS R., WEISS D., DUBBIN W., PEEL K., COLES B., ARNOLD T. Investigations into the kinetics and thermodynamics of $\mathrm{Sb}(\mathrm{III})$ adsorption on goethite (a-FeOOH). Colloid Interface Science, 303, 639, 2006.

21. XUEHUA LI, XIAOMIN DOU, JUNQING LI Antimony(V) removal from water by iron-zirconium bimetal oxide:Performance and mechanism. ScienceDirect, 24 (7), 1197, 2012

22. SUN F.H., HU X.W., GUO F., WU F.C. Biosorption of $\mathrm{Sb}$ (III) by Microcystis Aerosol Additive. Environmental Science Research, 29 (12), 1849, 2016
23. SUN F., SUN W.L. Biosorption behavior and mechanism of beryllium from aqueous solution by aerobic granule. Chemical Engineering Journal, 172 (2), 783, 2011.

24. HONG-TAO FAN, WEN SUN, BING JIANG, QING-JIE WANG, DA-WU LI, CONG-CONG HUANG, KANGJUN Z.Z.A.W., WANG A. Adsorption of antimony(III) from aqueous solution by mercaptofunctionalized silicasupported organic-inorganic hybrid sorbent:Mechanism insights. Chemical Engineering Journal, 286, 128, 2016.

25. FAN H.T., SUN W., JIANG B., WANG Q.J., LI D.W. dsorption of antimony(III) from aqueous solution by mercaptofunctionalized silica-supported organic-inorganic hybrid sorbent:Mechanism insights. Chemical Engineering Journal, 286, 128, 2016.

26. WAN C., WANG L., LEE D.J., ZHANG Q., LI J. Fungi aerobic granules and use of $\mathrm{Fe}(\mathrm{III})$-treated granules for biosorption of Sb5+. Journal of the Taiwan Institute of Chemical Engineers, 45, 2610, 2014.

27. XU W., WANG H., LIU R., ZHAO X., QU J. The mechanism of antimony(III) removal and its reactions on the surfaces of Fe-Mn binanr oxide. Joumal of colloid and interface science, 363 (1), 320, 2011.

28. ZHAO Z., WANG X., ZHAO C., ZHU X., DU S. Adsorption and desorption of antimony acetate on sodium montmorillonite. Colloid Interface Science, 345, 154, 2010.

29. ZHENG H., WANG Y., ZHENG Y., ZHANG H., LIANG S., LONG M. Equilibrium, kinetic and thermodynamic studies on the sorption of 4-hydroxyphenol on Crbentonite. Chemical Engineering Journal, 143 (117-123), 1173, 2008.

30. VASILIU S., BUNIA I., RACOVITA S., NEAGU V. Adsorption of cefotaxime sodium salt on polymer coated ion exchange resin microparticles: kinetics equilibrium and thermodynamic shudyies. carbohydr .Polym, 85, 376, 2011.

31. NAIYA T.K., BHATTACHARYA A.K., DAS S.K Adsorption of $\mathrm{Cd}(\mathrm{II})$ and $\mathrm{Pb}$ (II) from aqueous solutions on activated alumina. Colloid Interfaces Sci, 333, 14, 2009.

32. LAGERGREN S. About the theory of so-called adsorption of soluble substances. Kungliga Svenska Vetensk. Handl, 24, 1,1898

33. WANG J.J., LI X.N. Ion-imprinted composite hydrogels with excellent mechanical strength for selective and fast removal of $\mathrm{Cu}^{2+}$. Ind. Eng. Chem.Res., 52, 572, 2013.

34. JIMÉNEZ-CEDILLO M.J.,. OLGUÍN M.T, FALL C., COLIN-CRUZ A. As(III) and As(V) sorption on ironmodified non-pyrolyzed and pyrolyzed biomass from Petroselinum crispum (parsley). Journal of Environmental Management, 117, 242, 2013.

35. XU H., LIU Y. Mechanisms of $\mathrm{Cd}^{2+}, \mathrm{Cu}^{2+}$ and $\mathrm{Ni}^{2+}$ biosorption by aerobic granules $[\mathrm{J}]$ Separation and purification technology., 58 (3), 400, 2008.

36. PRADHAN S., SINGH S., RAI L.C. Characterization of various functional groups present in the capsule of Microcystis and study of their role in biosorption of $\mathrm{Fe}, \mathrm{Ni}$ and $\mathrm{Cr}$, Bioresour. Technol., 98, 595, 2007.

37. DAS S.K., DAS A.R., GUHA A.K. A study on the adsorption mechanism of mercury on Aspergillus versicolor biomass. Environment Science Technology, 41, $8281,2007$. 